Article

\title{
Gender and Struggles for Equality in Mining Resistance Movements: Performing Critique against Neoliberal Capitalism in Sweden and Greece
}

\author{
Angelika Sjöstedt Landén ${ }^{1, *}$ and Marianna Fotaki ${ }^{2}$ \\ ${ }^{1}$ Department for Social Sciences, Mid Sweden University, 83125 Sweden; E-Mail: angelika.sjostedt-landen@miun.se \\ 2 Warwick Business School, University of Warwick, Coventry, CV4 7AL, UK; E-Mail: marianna.fotaki@wbs.ac.uk \\ * Corresponding author
}

Submitted: 17 April 2018 | Accepted: 13 August 2018 | Published: 22 November 2018

\begin{abstract}
This article explores the intersections of gender and centre-periphery relations and calls for theoretical and political involvement in gendered struggles against colonial and capitalist forces across different national contexts. The article raises questions about the possibility of resisting inequality and exploitation arising from capitalist expansion and extraction of natural resources in Sweden and Greece, outside of urban contexts. It does so by highlighting women's role in protest movements in peripheral places and questioning power relations between centre and periphery. The article also argues that making visible women's struggles and contributions to protest movements brings about vital knowledge for realizing democratic worlds that do not thrive on the destruction of natural resources and the institutionalization of inequalities.
\end{abstract}

\section{Keywords}

activism; capitalism; extractivism; gender; Greece; mining; neoliberalism; protest; Sweden; women

\section{Issue}

This article is part of the issue "Gender Equality and Beyond: At the Crossroads of Neoliberalism, Anti-Gender Movements, 'European' Values, and Normative Reiterations in the Nordic Model”, edited by Lena Martinsson (University of Gothenburg, Sweden), Diana Mulinari (Lund University, Sweden) and Katarina Giritli Nygren (Mid Sweden University, Sweden).

(C) 2018 by the authors; licensee Cogitatio (Lisbon, Portugal). This article is licensed under a Creative Commons Attribution 4.0 International License (CC BY).

\section{Introduction}

In the European context, gender equality is now often framed in the language of neoliberal competition between nation states about occupying a higher rank in the Gender Equality Index (Sjöstedt Landén \& Olofsdotter, 2016; Verloo \& van der Vleuten, 2009). In this discourse of gender equality, centre-periphery relations, within or between national contexts, are rarely discussed. In the EU Gender Equality Index for instance, Sweden is ranked top and Greece is at the bottom (European Institute for Gender Equality, 2015). Nevertheless, Sweden's high-ranking obscures inequalities between regions and different populations, particularly concerning women in the North, and in Greece experiencing the greatest recorded peacetime economic depression (Coppola, 2018), who are the focus of this study. This ar- ticle explores the intersections of gender and peripherality and calls for theoretical and political involvement in gendered struggles against (neo)colonial and neoliberal capitalist forces from a transnational perspective, which, as we argue, apply equally in both countries. The aim of this article is to examine the ways in which women struggle against extractivism and mining, and how they go about making these struggles visible. The article raises questions about the possibility of resisting the inequality and exploitation arising from capitalist expansion and extraction of natural resources at the peripheries beyond urban contexts, of an egalitarian Northern European country (Sweden) and of the Eurozone country under a draconian austerity regime (Greece). We argue that a transnational perspective reveals the need for feminist solidarity between peripheries across national borders, despite the circulation of gender equality "suc- 
cess" stories. The study demonstrates that neoliberal extractivist expansion is trampling on gender rights in both Sweden and Greece. Our task as feminist intersectional researchers is to uncover how the gender equality discourse may become instrumental to capitalist accumulation, including the "devastation of natural resources", "exploitation of human and non-human life" and reifications of "desirable and undesirable people" (de los Reyes, 2016, p. 40).

Two issues lie at the centre of the analysis, namely the need to account for women's contributions to anti-mining struggles, and women's capitalist critique through protest movements. Specifically, we focus on our observations of the expanding extraction and exploitation of natural resources (Haikola \& Anshelm, 2017) in both Sweden and Greece. This recent "mining boom" is widespread and global and yet it depends on the economic and political context in which it takes place; equally, women's opposition to these developments comprises distinctive local characteristics. Research indicates that women are directly affected by the material reality of natural resource extraction and are often the first to realize what is happening when companies arrive to establish or re-open mines (for a review, see Jenkins, 2014). This is because extraction and mining-as well as neoliberal states-are gendered regimes (Jenkins \& Rondón, 2015; Stienstra, 2015). Various forms of resistance are performed by women against extractivist forces that organize political, socio-economic and cultural relations, including the use of gender relations to profit multinational mining companies (see Conde, 2017); yet such initiatives, we argue, do not necessarily build on mass protest and assembly, although they may certainly lead to such action.

The article examines parallels in women's resistance through activist movements emerging in response to the destructive consequences of extractive mining in their communities. In sharing examples from our previous work on women's struggles against mining in both countries, we aim to promote initiatives that counteract the invisibility of women and their struggles against neoliberalism in areas that are deemed marginal in both Sweden and Greece, thereby challenging the mainstream gender equality discourse at national and EU levels. In drawing attention to the role of women's struggles in peripheries, we also spearhead the critique against (neo)extractivism as a form of neoliberal capitalism and its various ways of institutionalizing inequalities.

\section{Gender, Activism and Critique of Neoliberal Capitalism}

In a recent review article on changes in protest movements against mining, Martha Conde (2017) observes that the role of violence in mining conflicts is understudied, as is the role of gender in counteracting mining expansion. As gender scholars, we also know that gender and violence are inextricably linked in many and var- ied ways in society. Yet women's role in protest movements and their willingness to engage in anti-mining resistance is relatively unexplored, even though women and indigenous women specifically, often play a crucial part in protest movements (Giacomini, 2015; Jenkins \& Rondón, 2015; Nabulivou, 2006). While women's work is sometimes conducted behind the scenes, scholars have called for recognition of women's increasing agency and their capacity for self-organization in addressing mining-related concerns (Lahiri-Dutt, 2012). The study addresses this gap by making visible the issue of women's (in)visibility, which is not only key to gender equality, but is also important for understanding different forms of resistance to extractivist mining specifically. In doing so we take an inspiration from Judith Butler's (2015) work on precarious bodies suffering from neoliberal dispossession and the ways they enact their capacity to resist it by making their concerns public as they gather in the same space to make themselves visible. Butler draws on examples from recent protest movements conducted in city squares and public parks to construct her notion of a performative role of assembly. Demands for equality are thereby linked with the appearance of plural bodies in the same space: "If we appear, we must be seen, which means that our bodies must be viewed and their vocalized sounds must be heard: the body must enter the visual and audible field" (Butler, 2015, p. 86). However, mining activities are usually conducted in rural areas. Populations are dispersed and communities become fragmented by mining initiatives, while companies are often keen to place mines in sites where local populations are considered to be unimportant: for the disruption and destruction of their livelihoods does not appear to carry a significant political cost. These, for instance, may include indigenous populations who are not "meant to" exist on their own terms. Often, such struggles are made invisible by marginalizing the concerns of these populations, and specifically women, in societies that are otherwise understood to be highly egalitarian (Horowitz, 2017; Willow, 2016). This suggests that social institutions in such societies continue to be organized on an unequal basis, and that awareness of this inequality can be hidden if relegated to spaces that are considered to be "dumping grounds" (Lawson, Jarosz, \& Bonds, 2010), "invisible" (Licona \& Maldonado, 2014), or "no man's lands" (Lawrence \& Åhrén, 2017, p. 150). Mining companies often contribute to invisibilizing these spaces as they create a new kind of enclosure for locals, turning commons into privately-owned gated spaces (Sassen, 2013). The transformation of public goods into private consumerist commodities is a central feature of neoliberalism (see e.g., Fotaki, 2017, for a discussion of public health examples). But not seeing and acting as if there were no people or culture in a space is at the heart of colonialist power and its alignment with capitalism (Harris, 2004). Research on the politics and experiences of indigenous protests, for example from Latin America, shows how indigenous peoples and women are lead protagonists 
in the struggle against neoliberalism (Rice, 2012, p. 3). Moreover, protests on the grounds of indigeneity bring to the fore ways of demarcating "the people" who may not necessarily strive for inclusion in terms of nationstate categories. In this article, we focus on examples from Sweden and Greece to demonstrate how protests against extractions occur in spaces that can be categorized as "hidden" from the (urban) public eye. Specifically, we examine women's role in initiating protests against extractivist mining, which are often conducted in remote locations.

The first contribution our study makes is to account for women's involvement in the anti-mining struggle and women's anti-capitalist critique through protest movements. The second, and related, contribution is to apply gender analysis as a means for counteracting capital expansion, and the dispossession and fragmentation of communities it brings about. Third, our focus on marginalized populations and spaces speaks to a broader critique of the centre/periphery binary, which divides populations on the basis of locations and their interaction with neoliberal logics. In bringing women's struggles to the forefront, feminist analysis opposes the process companies and states employ to render these places and populations inhabiting them invisible. The academic studies are often limited to the concerns of "the centres" but studying developments in peripheral economies and communities opposed to capitalist interests deserves more research attention. Much of the social movement literature's focus on the urban mass protests may (involuntarily) contribute to the ongoing construction of centres and peripheries that enables colonialism, capitalism and patriarchy to reproduce and thrive. Feminist ontology is well positioned to break with narratives emphasizing the need to stimulate the competitiveness of centres "in a global bidding war for footloose businesses" (Hermansson, 2013, p. 3). Overall, the article contributes to a feminist literature on protest movements by bringing in a perspective of the rural periphery to extend the body of research claiming that "across the globe resistance is played out by bodies that occupy pavements, streets and squares" (see e.g., Lilja, 2017, p. 342, with reference to Butler, 2015). The occupied spaces can also be located in sparsely populated areas, for example, in forests, gravel roads, hills and mountains. Such different modes of performativity of assembly, we suggest, opens up possibilities for often-silenced critiques of capitalism and patriarchy that cut across gender, ethnicity, sexuality and class (Horowitz, 2017; Pini \& Mayes, 2013).

\section{Extractivism in Sweden and Greece}

The concept of extractivism is strongly connected with colonization and modern capitalism, and is thus also deeply linked to the dichotomized power relations of centre/periphery. This "extractivist mode of accumulation...has been determined ever since by the demands of the metropolitan centres of nascent capitalism" (Acosta,
2013, p. 62), although more recently, consideration of social "sustainability" and "equality" is often included in states' public policy, nevertheless, lending support to neo-extractivist agendas (Acosta, 2013, pp. 71ff.). It is commonly believed that Sweden has no colonial history. Yet since the post-WWII era, the Swedish state has been the sole owner of mining companies in Sweden, established largely through the colonization of Sami land (Lawrence \& Åhrén, 2017). Such "colonial complicity" (Keskinen, Tuori, Irni, \& Mulinari, 2009) is part of the hegemonic discourse of Sweden, which is simultaneously a country where support for human rights and gender equality ideals are a reality (Martinsson, Griffin, \& Giritli Nygren, 2016). The current goal of public policy is to make Sweden an attractive country for mining industries in the global market. This is being achieved partly by charging relatively low fees for extracting minerals from Swedish grounds (Tillväxtanalys, 2016). Sweden has not been affected by the recent global financial crisis and its economy is growing. This is largely attributed to the neoliberal reforms centred on cutting costs and privatizing public services introduced by the consecutive conservative and social democratic governments in the last two decades (Hammerschmid, Van de Walle, Andrews, \& Bezes, 2016). By comparison, Greece is the weakest Eurozone member that was severely affected by the 2010 Eurozone crisis with women bearing the brunt of the cost of the financial crisis including high unemployment and the retrenchment of public services (Daskalaki \& Simosi, 2018; Fawcett Society, 2012). Historically, it scored low on gender equality and is still at the bottom of the European gender ranking. The ensuing neoliberal austerity (Charitsis \& Velegrakis, 2013) and the rapid decrease of foreign investment in a heavily-indebted country led to governments' endorsing the "low cost", but highly environmentally-damaging, open-pit gold mining in Northern Greece. The expectation was that this would help resolve the country's indebtedness while addressing the issue of high unemployment. In short, while Greece was struck very badly in the aftermath of the global financial crisis and was being made a scapegoat for problems inherent in the Eurozone design, Sweden was largely unaffected; yet both countries are striving to attract mining companies from countries such as Canada, Great Britain and Australia. And while the purpose of attracting investment is different in each case, the logic of neo-extractivism is similar. In both cases, there is opposition to planned and ongoing mining activities by movements opposing to what they perceive as transnational acts of colonization and exploitation altering people's living environments and threatening their (cultural and material) existence. Hence, extractivism and exploitation can be understood as an ongoing crisis from the perspective of mining resistance movements (Stienstra, 2015). Moreover, in both countries, resistance is also directed against the state's implementation of neoliberal policies that hit hard the rural regions that are deemed peripheral. 


\subsection{Mining and Neoliberal Policy in Sweden}

Sweden is currently ranked as one of the world's most attractive countries for mining investment (Tillväxtanalys, 2016 , p. 11). The low cost of mining has led to the country being described as an Eldorado for global mining investors in recent years (Müller, 2013; Tidholm, 2012). Animated public debate has ensued on whether intensive resource exploitation should continue, given the conflicting interests involved (Haikola \& Anshelm, 2016). For instance, estimates of the number of jobs that might be created by establishing new mines have been increasingly questioned (e.g., Haikola \& Anshelm, 2017; Henriksson, Juhlin, \& Pistol, 2015; Müller, 2015), and contrasted with the jobs that the mines might destroy. Examples have been presented of mining projects creating huge costs for municipalities with declining revenues from taxation, along with instances of tensions in the local economy, and severe environmental pollution (Müller, 2015). Moreover, locating the new mines in sparsely-populated regions in Northern Sweden, in inland areas fitting Lawson et al.'s (2010, p. 664) definition of "dumping grounds", suggests that mining is part of Swedish colonial history. As a result, "the rural regions become weak players in new rounds of corporate consolidation", including a "race to the bottom" in a chase for new investments (Lawson et al., 2010, p. 664).

The North of Sweden, where historical Sápmi ${ }^{1}$ lands are located, have consistently been treated as an internal colony with an "infinite depot of raw materials" (Lawrence \& Åhrén, 2017, p. 157). Since the 1600s, industrialization and colonialism have gone hand in hand through regulating and the subsequent commodification of space and people (Nordin, 2015). There are only a few urban centres in this part of the country, with long distances between communities. Forestry, tourism, reindeer herding, fishing, hunting and berry picking are core economic activities. Different types of colonial practices and categories of internal colonialism, especially in relation to indigenous people, can be traced back to the processes of exploration and exploitation of new mines. The government's current mineral strategy (Näringsdepartementet, 2013, p. 26) states, among other things, that: "the government is taking action aimed at promoting a living Sami culture based on ecologically sustainable wastewater treatment, as well as strengthening the ability of Sami to influence these decisions". It also states that the Sami are recognized as Sweden's only indigenous people. However, Haikola and Anshelm's (2016, p. 512) analysis of the Swedish government's mineral strategy shows that the opposite is true, since its previous colonial practices have been intensified under this strategy. For instance, Haikola and Anshelm (2017) identify a marked shift toward a neoliberal mineral policy since 2013. In this context, Sami organizations report a new kind of aggressiveness in authorities' actions that are directed against their community. Their criticism of the government's mineral strategy centres on making visible the concrete ways in which life in places where the new mines are planned and where they have already opened is negatively affected (Haikola \& Anshelm, 2016, p. 512). These criticisms emphasize the short- and longterm social, economic and environmental impacts of mining on the Sami communities. Their aim is to open up debate on how mining might bring benefits and prosperity for local (Sami and non-Sami) populations and the environment at large. A number of important issues have been raised following these critical approaches, such as the impact of prospective job losses on communities when mines close and the long-term environmental and social problems that they leave behind such as diminished Sami rights, that could make communities even more vulnerable to future exploitation by new mines (Haikola \& Anshelm, 2016, p. 513). This is symptomatic of a neo-extractivist stance, whereby countries with progressive governments may be aware of some of the ills of extractivism without genuinely seeking to overcome their reliance on this mode of accumulation beyond the level of discourses and plans (Acosta, 2013, p. 72).

More importantly for women's rights and resistance, incorporation of indigenous societies into the capitalist economy has historically "been highly gendered and has had many gender-specific consequences" (Kuokkanen, 2009 , p. 503). For instance, it has resulted in the loss of Sami women's status, including their distinctive way of life and their specific role in securing the livelihood of their communities, while making the policies regulating it invisible. Women have opposed these developments by participating in many movements protesting the establishment of new mines all over Sweden. Here, we bring examples from an ethnographic research project highlighting three cases of resistance movements in the most sparsely populated Northern parts of Sweden. None of these was constructed as a women's movement, but women took active positions and were central to initiating and sustaining these protests. Two of these cases investigate mobilizations of Sami communities (Sjöstedt Landén, 2014, 2017a), while the third examines their role in agricultural and land-owning disputes (Sjöstedt Landén, 2017b). While women's participation in protests is typically linked with various other struggles, such as opposition to nuclear power and battles for ratification of the ILO 169 Convention (Sjöstedt Landén, 2017a), the examples of Swedish protest movements that are outlined next, all concern resistance to the prospect of establishing new mines (Sjöstedt Landén, 2017a).

During the summer of 2013, a protest camp was set up at the Gállok/Kallak exploration area in woods outside Jokkmokk, where both locals and protesters from other parts of Sweden and elsewhere tried to stop Beowulf

\footnotetext{
${ }^{1}$ Sápmi is the name of the land of the Sami and covers roughly the northernmost parts of Norway, Sweden, Finland and the Kola Peninsula in the Russian Federation. The Sami are the indigenous people of northern Fennoscandia, as defined, for example, in International Labour Organization (ILO) Convention 169, which has not been ratified by Sweden (see e.g., Nordin, 2015, p. 251).
} 
Mining's exploration for iron ore. The events in the municipality of Jokkmokk eventually attracted national and international interest (Lundberg Tuorda, 2014; Sjöstedt Landén, 2014). Several female and feminist artists and musicians were at the forefront of mobilization against the mine (see e.g., Sandström, 2017). Publicity the protest movements opposing such developments gain is crucial to how problems are defined and struggles initiated and sustained. Marie Persson and May-Britt Öhman (2014) describe the magnitude of devastation that development of a nickel mine would cause to the local community of Rönnbäcken in Björkvattsadalen in the municipality of Storuman. A mine would affect a huge area including urban centres, as a result of polluted water and the risk of dam rupture. They raise awareness of everyday life and share pictures of children picking berries and doing other activities: "Our life with nature-fishing, hunting, handicraft-we cannot live here if land and water are destroyed" (Persson \& Öhman, 2014, p. 107). Struggles for land and water should therefore be seen as a cultural struggle for people to have the opportunity to define their lives (Escobar, 2001, p. 162).

Activists in Sweden also point to the difficulty of taking frontline positions in resistance movements in small places because, at a local level, they may become "too visible" and vulnerable to violence because of their engagement (e.g. Sjöstedt Landén, 2014). Openings of new mines are connected with threats of violence and violations to women's lives in various ways, particularly for those engaged in anti-mining activities. One female activist who led a protest in a Swedish village advertised to prospecting companies looking for uranium in the Oviken area in the municipality of Berg told a story of how she found a sign by the road to her house saying: "there is too much pussy here". The activists' hand-painted signs against the mining project had been taken down and instead there were a lot of signs saying, "yes to jobs" and "yes to the mine". The village schoolchildren tore down those signs, but finally, the antagonist "made a sign that was based on a giant iron plate that he welded to the wall. It was also 'yes to mining', 'yes to jobs'” (see also Sjöstedt Landén, 2017b, p. 175). The woman telling this story ended by noting that at that time she had been fearful of being followed, or of someone coming up to her house at night. These are some short examples of how protests become embodied in a way that is connected to materiality and topography that is different from streets and squares. Woods, lakes and streams, mountains, and village roads make out the material conditions that define life, livelihood, and social relations and cannot only be understood as temporarily occupied spaces.

\subsection{Greek Neoextractivism in the Context of Crisis}

Greece provides an important contemporary case study of the emergence of the political economy of extractivism in the aftermath of the global financial and the ensuing Eurozone crises. As the most vulnerable Euro- zone country, Greece was no longer able to borrow on the capital markets after its indebtedness was exposed in 2010. This was exacerbated by harsh austerity measures following the flawed "bail out" (Independent Evaluation Office, 2016) administered by a troika of lenders comprising the IMF, the European Commission and the European Central Bank. In the process, the Greek government lost control of its internal policy and had to accept what the troika dictated. In line with the lenders' recommendations, attracting investment has become imperative for all post-crisis Greek governments. Transnational capital and global financial institutions such as the IMF consider Greece as a "resource rich but cash poor and indebted" state (Charitsis \& Velegrakis, 2013). Hence, extractivism is promoted as a "win-win" development model, despite its highly problematical social, spatial, ecological and political outcomes for the area (Charitsis \& Velegrakis, 2013). Eldorado Gold, a low-cost Canadian mining company, has declared its willingness to invest a billion US dollars as part of a plan eventually to source up to $30 \%$ of its global gold production in Greece (Tsavdaroglou, Petrakos, \& Makrygianni, 2017), despite a documented case of the company's tax-dodging practices (Hartlief, McGauran, Van Os, \& Römgens, 2015).

The case considered here involves extractivism and a resistance movement initiated by women (S.O.S. Halkidki) against extractive mining. This was launched in Chalkidiki Peninsula in Northern Greece, which is a very popular tourist destination and has a diverse and biologically important natural landscape, combining mountains, forests, sea and beaches. Besides tourism, the local economy is based on agriculture, livestock, fishing, beekeeping and forestry. Eldorado Gold, which owns all gold projects currently in development or operating in Greece, has now cleared an old forest to build Greece's first and biggest open-pit gold mine as well as an underground mine. Soon after gaining power in 2015, the left-leaning Syriza party, which was initially against the Canadian-owned gold mine's expansion plans, capitulated to all the lenders' demands and subscribed to the "development at any cost" ideology that characterizes neo-extractivism (Gudynas, 2010). At the same time, regional competition for resources and pressure to curb high unemployment have led to a gradual shift in European attitudes and policies toward mining. As an analyst from the Raw Materials Group (Thomas, 2013) explains, the rise of resource nationalism in many parts of the world is making Europe more attractive from a low political risk perspective.

The anti-mining protest initiated by women in the Chalkidiki region is a flagship example illustrating how extractivism has been challenged, with protests not confined merely to the immediate locale, but developing into one of the main social movements and expressions of social conflict in Greece (Charitsis \& Velegrakis, 2013). Local communities affected by the extractive industry's activities are leading this social movement, strongly opposing the industry's development model and generally 
questioning the neoliberal onslaught on life and communities. In the following, we give examples on the forms of resistance exercised by S.O.S. Halkidiki, a women's activist movement against gold mining in Northern Greece. This case emerged from a larger ethnographic project (Fotaki \& Daskalaki, 2018), and many of our respondents did not identify themselves as explicitly feminist, but their means of struggle and contribution to undermining neoliberal capitalist "development" lie at the heart of feminist goals promoting social change along the lines of equality and empowerment.

The example of anti-mining activities in Skouries in Chalkidiki shows women using their bodies to oppose extractivism through emplaced forms of protest by women (and minoritized others) attempting to reclaim their living space (Fotaki \& Daskalaki, 2018). They use their bodies to demonstrate the destructive impact of mining on the environment and their communities, as they are often the first to experience the social and health burdens of extractivism. This inspires others and enables women to build conditions within broader activist movements to protest against mining corporations' activities. However, we should not underestimate the heavy price women often pay for their resolve and commitment, in terms of mental health issues, domestic violence and threats by those in the community who benefit from mining (Jenkins \& Rondón, 2015). In our case, women who chained themselves to a wire fence separating the mining site from the public space were brutally removed by the police, even though their protest was peaceful. In both the Greek and Swedish cases presented here, we see how women put their bodies in the frontline of protest, thereby exposing themselves to various threats of violence originating from national policy level down to personal relationships in the local communities in which they live. These costs and threats are ubiquitous and intrinsic to their struggle. However, activists also point to examples from mining protests where prospecting and mining has divided communities and made solidarity between women difficult. These phenomena have also been observed in Greece, where unemployment reached $27 \%$ in 2016, with a worse impact on female employment in post-crisis Greece (Vaiou, 2014), leading to intercommunity divisions and an increase in gender violence. In the case of Skouries in Chalkidiki, some local women ultimately followed the example of Eldorado's male miners/employees in deciding to become site guards.

\section{Gender in Mining Resistance in the Periphery}

These brief examples of the anti-mining gender struggle from Sweden and Greece that were brought together address the issue of the invisibility of women's central role in protest movements while also showing how invisibility frames the periphery/centre relationships in neoliberal capitalism. In both countries, mining activities are located in distant rural locations that are very sparsely (Sweden) or relatively sparsely populated
(Greece). In her work on embodied resistance against injustice, Butler (2015) primarily emphasizes the materiality of the street. Yet, she also acknowledges the dislocated character of urban movements and their spread between different (urban) "locales" in online contexts. Protest movements in sparsely populated areas also rely on online platforms and social media as an important means of organizing protest. Sjöstedt Landén's (2017a) examination of how mining protests in Sweden might be sustained through Facebook pages reveals that this is not only a strategy for spreading a message, but might also be seen as a way of populating spaces deemed empty and thus open to extraction (Sjöstedt Landén, 2017a). Online platforms are also used to extend the notion of the local community (Dahlberg-Grundberg \& Örestig, 2016). For example, Facebook pages can be seen and "liked" by thousands of people, even though there may be only one or very few people at the protest site. Transnational feminist and indigenous movements are vital actors in linking local protests and pointing to the global character of extractivism and its negative effects on women. Facebook and other social media are only one of many different arenas in which struggles occur over definitions of the meaning of places and activities that should or should not happen in these spaces, which are important for both life and cultural reproduction. This also helps counteract the image of rural and sparsely populated spaces as empty areas that enables exploitation by the mining companies. Therefore, the visibility mediated, amongst other means, by Facebook and other digital platforms has an important political significance. Social media do not automatically make people more active but, for some, they may be a way of participating more actively in an extra-parliamentary political landscape in which alternative visions for local communities and society can be presented beyond the so called "mining boom". This also becomes a way of "populating" protest in invisible spaces. We propose that these are important means for counteracting practices of deeming a place to be "peripheral" which is only beneficial for the current and future exploiters. A clear example is the ongoing prospecting for iron ore in the municipality of Jokkmokk. At a conference with investors, the CEO of British investment company Beowulf Mining stated that, when asked what locals think about mining in the neighbourhood, he usually answers "what local people?" The publicity that this statement attracted has led to new forms of resistance, for example on the website whatlocalpeople.se, where descriptions of the exploration areas are made visible in the statement "we are the local people" (see Cocq, 2014; Lundberg Tuorda, 2014).

In Greece, with the anti-mining protest taking place in a remote area, the movement (which included many women) also relied on digital platforms and websites set up specifically to report on the struggle in Chalkidiki, namely S.O.S. Halkidiki, Save Skouries and AntiGold Greece, as important and powerful tools for publicizing the goals and objectives of the anti-mining struggle. 
These served as ways of sharing information and support building for local community struggles, many of which were initiated by women. The activists use newsletters and email updates as well as scientific environmental reports on Eldorado's proposed and actual excavations in their online communications. The latter include an Environmental Justice Atlas report (Frezouli, 2014, p. 14) certifying the importance of the forest for the local population's livelihood:

The open-pit gold copper ore mine will result to the destruction of a primitive forest, the drainage of the aquifers and to the pollution of atmosphere and land. The method of "flash smelting" that will be used has never been used in industrial scale production in the past and there are fears that the company will finally implement the method of cyanation.

Finally, visual materials, such as videos on YouTube of women inserting their bodies as a form of protest to prevent excavations (discussed above), were widely shared on social media, and were important for mobilizing people to take to the streets in support marches in the cities of Athens and Thessaloniki (Fotaki \& Daskalaki, 2018). The women's movement in Skouries built alliances and supported other projects opposing neoliberal policies, such as water privatization in Thessaloniki (Daskalaki \& Fotaki, 2017). Conde's (2017) review reveals a shift in the strategies used in resistance to mining movements over the last couple of decades. Alliances with extra-local actors have played an important role in this shift:

Not only fostering movements to emerge, but also developing solidarity and political opportunities, facilitating the acquisition or co-production of technical knowledge and allowing for the emergence of alternative imaginaries of development. (Conde, 2017, p. 87)

Drawing on research on activism in other locales, including Canadian and indigenous contexts, Stienstra (2015, p. 647) raises the question of how relationships and caring occur under the crisis conditions imposed by mining exploitation on those living with its consequences and resisting it on a daily basis:

This view of crisis illuminates how the local is intricately embedded into and reliant upon global political, economic and military relationships. It illustrates those included in and necessary for those global political, economic and military relationships (workers, miners, pilots, civilian staff, etc.) as well as those excluded from and seen as unnecessary to these relationships (women, Indigenous peoples, people with disabilities, care providers, etc.).

Women's opposition to environmentally and socially destructive extractivist mining demonstrates "the state of exception" (Klein, 2007) introduced by the crisis, specif- ically in the case of Greece. But the same state of exception, has also enabled the extension and reproduction of the enduring colonial societal structures of extractivism implemented on the lands of indigenous populations in Northern Canada (Willow, 2016), New Caledonia (Horowitz, 2017) and Latin America (Jenkins \& Rondón, 2015). With reference to rural communities in the Andes, Jenkins and Rondón (2015) argue-along with Stienstra-that attending to women's experiences as anti-mining activists forces us to remember how continuing and extreme power inequalities enable the neoliberal extractivist model to dominate, and why such responses are necessary to counteract this. According to Haikola and Anshelm (2017, p. 2, with reference to Butts, 2015; Stuermer, 2013), in a neoliberal era, the extractive industries hold a special position:

Their recurring cycles of boom and bust keep alive the promise of rapid industrialization and economic growth for peripheral communities that have found themselves on the losing end of the neoliberal restructuring of the economy, and they retain a strategic value within a context of resource security that is often highlighted by nation states in periods of regional and global instability or temporary drops in supply.

However, as Butler and Athanasiou (2013, p. 39) argue, "there is nothing merely economic about economics" because "economy" has become a way to distinguish populations that are considered "superfluous" and unnecessary in a certain kind of "economy" (2013, p. 40). This also teaches us about the effects of the interplay between peripheralization and dispossession. As Stienstra (2015, p. 647) puts it:

With a focus on the local and those often excluded we recognize that an important story is of agency and resistance in crises. With the persistent involvement of Indigenous nations, women and others who resist, alternatives are imagined and created.

Morgan's (2017) study of women participating in protest movements in Indonesia shows that while dominant gender relations tend to exclude women from politics, the presence of women in protests may open up possibilities, in that rural struggles around land and dispossession may simultaneously serve as sites of struggle over changing gender regimes through their active participation in them.

\section{Conclusions: Performing Critique against Neoliberal Capitalism}

This article has addressed the relatively underresearched issue of women's resistance in sparsely populated contexts from a gendered perspective. It has demonstrated that women use diverse ways to resist and build support similar to those in urban localized 
protests, and has also highlighted the existence of longterm movements for indigenous peoples' rights around the world, often expressed through protests against various types of exploitation in non-urban environments. These are not fixed relations, and it is important to scrutinize how such movements affect gender relations in different times and under different regimes.

Our conclusion is that attending to gender in mining protests provides us with vital resources for opposing neoliberal capitalism, for instance by highlighting how minority populations that include indigenous women in rural locales organize themselves and their communities to oppose extractivist mining. Such issues are often omitted from discussions of gender equality policy, perhaps because their intersectional character is not addressed and they critique national narratives whenever gender equality is not linked with national projects (Martinsson et al., 2016, p. 4). We suggest that our examples highlight important aspects of how different inequalities (e.g., of gender, class, ethnicity) intersect with one another and provide a potential way to politicize the concept of gender equality. Women in anti-mining protests possess vital experiential knowledge of how gender inequality materializes in society, and may also teach us about how it can actually be resisted. In both our examples (Sweden and Greece), women are often seen as, and are in reality, family carers, so they are closer to the immediate risks of mining, both materially and symbolically. Therefore, as we argue, struggles against mining are ridden with invisible work, which often becomes the task of women. In both cases, the women also refused to be made invisible. Resistance to being made invisible is becoming an important part of the extractivist anti-capitalist critique. We therefore suggest a need to emphasize the (in)equality issues that are brought to the fore when activists talk about gender, including the invisibility of women's contributions and the silencing of their concerns in anti-mining activism. The feminist analysis, which raises questions about gender, may also be an effective way of formulating the extraction of natural resources as an ongoing crisis of capitalism.

In focusing on these initiatives, this article thus contributes to counteracting the process, core to neoliberal capitalism, of turning some regions and countries into exploitable invisible peripheries (Kousis, 2014). The process of "peripheralization" is indispensable for neoliberal capitalist expansion, for it enables the dispossession of populations. We have attempted to counteract this invisibility by populating "empty" places, showing how women struggle against these divisions of local community populations when mining initiatives are put into practice, and how they refuse to be divided. Highlighting the role of women in protest movements in peripheral places reveals how power relations between centre and periphery may be disrupted. Making visible the invisible struggles and contributions of women in protest movements also brings vital knowledge for realizing democratic worlds that do not thrive on the destruction of natural resources and the institutionalization of inequalities; something that should be core to discussions of gender equality.

\section{Acknowledgements}

The authors would like to thank the editors of the thematic issue and two anonymous reviewers for valuable comments to earlier versions of the article. Marianna Fotaki would like to thank Professor Maria Daskalaki with whom she has worked together on a larger project on Skouries Chalkidiki and the British Academy of Management for partly funding this research. The Swedish case studies were funded by the Swedish Research Council (421-2014-1584).

\section{Conflict of Interests}

The authors declare no conflicts of interest.

\section{References}

Acosta, A. (2013). Extractivism and neoextractivism: Two sides of the same curse. In M. Lang \& D. Mokrani (Eds.), Beyond development: Alternative visions from Latin America (pp. 61-86). Quito, Ecuador: Fundación Rosa Luxemburg.

Butler, J. (2015). Notes toward a performative theory of assembly. Boston, MA: Harvard University Press.

Butler, J., \& Athanasiou, A. (2013). Dispossession: The performative in the political. Cambridge: Polity Press.

Butts, K. (2015). Geopolitics of resource scarcity. Penn State Journal of Law \& International Affairs, 3, 1-9.

Charitsis, A., \& Velegrakis, G. (2013). The energy sector in Greece: Industrialization, privatization and social resistance. In M. Gensler (Ed.), Energy policy and resource extractivism: Resistances and alternatives. Brussels: Rosa Luxemburg Stiftung.

Cocq, C. (2014). Kampen om Gállok: Platsskapande och synliggörande. Kulturella Perspectiv, 1, 5-11.

Conde, M. (2017). Resistance to mining. A review. Ecological Economics, 1(32), 80-90.

Coppola, F. (2018). The greatest depression. Forbes. Retrieved from www.forbes.com/sites/francescoppola/ 2018/07/31/the-greatest-depression/\#27b46c76346d

Dahlberg-Grundberg, M., \& Örestig, J. (2016). Extending the local: Activist types and forms of social media use in the case of an anti-mining struggle. Social Movement Studies, 16(3), 309-322.

Daskalaki, M., \& Fotaki, M. (2017). The neoliberal crisis: Alternative organizing and spaces of/for feminist solidarity. In A. Pullen, N. Harding, \& M. Phillips (Eds.), Feminists and queer theorists debate the future of critical management studies: Dialogues in critical management studies volume 3 (pp. 129-53). Bingley: Emerald Publishing.

Daskalaki, M., \& Simosi, M. (2018). Unemployment as a liminoid phenomenon: Identity trajectories in times 
of crisis, Human Relations, 71(9), 1153-1178.

De los Reyes, P. (2016). When feminism became gender equality and anti-racism turned into diversity management. In L. Martinsson, G. Griffin, \& K. G. Nygren (Eds.), Challenging the myth of gender equality in Sweden (pp. 23-48). Bristol: Policy Press.

Escobar, A. (2001). Culture sits in places: Reflections on globalism and subaltern strategies of localization. Political Geography, 20, 139-174.

European Institute for Gender Equality. (2015). Comparing in Gender Equality Index. Retrieved from http://eige.europa.eu/gender-equality-index/2015/ countries-comparison

Fawcett Society. (2012). Policy briefing: The impact of austerity on women. Retrieved from http://www. fawcettsociety.org.uk/wp-content/uploads/2013/02 /The-Impact-of-Austerity-on-Women-19th-March2012.pdf

Fotaki, M. (2017). Relational ties of love: A psychosocial proposal for ethics of compassionate care in health and public services. Psychodynamic Practice, 23(3), 181-189.

Fotaki, M., \& Daskalaki, M. (2018). Politicizing the body: Women protesting against extractivist mining in Greece. Manuscript submitted for publication.

Frezouli, E. (2014). Gold mining in Halkidiki, Greece. Retrieved from https://www.ejatlas.org/print/goldmining-in-chalkidiki-greece.

Giacomini, T. (2015). Ecofeminism and system change: Women on the frontlines of struggle against fossil capitalism and for the solar commons. Canadian Women Studies/Les cahiers de la femme, 31(1/2), 95-102.

Gudynas, E. (2010). The new extractivism of the 21st century: Ten urgent theses about extractivism in relation to current South American progressivism. Washington, DC: Americas Program Report, Center for International Policy.

Haikola, S., \& Anshelm, J. (2016). Mineral policy at a crossroads? Critical reflections on the challenges with expanding Sweden's mining sector. The Extractive Industries and Society, 3(2), 508-516.

Haikola, S., \& Anshelm, J. (2017). The making of mining expectations: Mining romanticism and historical memory in a neoliberal political landscape. Social \& Cultural Geography. doi:10.1080/14649365.2017. 1291987

Hammerschmid, G., Van de Walle, S. Andrews, R., \& Bezes, P. (Eds.). (2016). Public administration reforms in Europe: The view from the top. Cheltenham: Edward Elgar Publishing.

Harris, C. (2004). How did colonialism dispossess? Comments from an edge of empire. Annals of the Association of American Geographers, 94(1), 165-182.

Hartlief, I., McGauran, K., Van Os, R., \& Römgens, I. (2015). Fool's gold: How Canadian firm Eldorado Gold destroys the Greek environment and dodges tax through Dutch mailbox companies. Amsterdam: Cen- tre for Research on Multinational Corporations.

Henriksson, J., Juhlin, M., \& Pistol, A. (2015). Samhällsomvandling som följd av eventuell gruvetablering $i$ Jokkmokk [Societal change in the wake of mining establishment in Jokkmokk]. Sweden: Jokkmokks Kommun.

Hermansson, K. (2013). The relevance of periphery for economic policy (editorial). Fraser Economic Commentary, 4, 4-5.

Horowitz, L. S. (2017). "It shocks me, the place of women": Intersectionality and mining companies' retrogradation of indigenous women in New Caledonia. Gender, Place \& Culture, 24(10), 1419-1440.

Independent Evaluation Office. (2016). The IMF and crises in Greece, Ireland and Portugal: An evaluation by the Independent Evaluation Office. Washington, DC: Independent Evaluation Office of the International Monetary Fund.

Jenkins, K. (2014). Women, mining and development: An emerging research agenda. The Extractive Industries and Society, 1, 329-339.

Jenkins, K., \& Rondón, G. (2015). "Eventually the mine will come": Women anti-mining activists' everyday resilience in opposing resource extraction in the Andes. Gender \& Development, 23(3), 415-431.

Keskinen, S., Tuori, S., Irni, S., \& Mulinari, D. (2009). Complying with colonialism: Gender, race and ethnicity in the Nordic region. London: Routledge.

Klein, N. (2007). Shock doctrine: The rise of disaster capitalism. New York, NY: Picador.

Kousis, M. (2014). Environment, economic crisis and social movements in Greece, under Troika memoranda and austerity policies [in Greek]. In S. Zambarloukou \& M. Kousi (Eds.), Social aspects of the crisis in Greece (pp. 199-229). Athens: Pedio.

Kuokkanen, R. (2009). Indigenous women in traditional economies: The case of Sami reindeer herding. Signs: Journal of Women in Culture and Society, 34(3), 499-504.

Lahiri-Dutt, K. (2012). Digging women: Towards a new agenda for feminist critiques of mining. Gender, Place \& Culture, 19(2), 193-212.

Lawrence, R., \& Åhrén, M. (2017). Mining as colonization: The need for restorative justice and restitution of traditional Sami lands. In L. Head, K. Saltzman, G. Setten, \& M. Stenseke (Eds.), Nature, temporality and environmental management: Scandinavian and Australian perspectives on peoples and landscapes (pp. 149-166). London: Routledge.

Lawson, V., Jarosz, L., \& Bonds, A. (2010). Articulations of place, poverty, and race: Dumping grounds and unseen grounds in the rural American northwest. Annals of the Association of American Geographers, 100(3), 655-677.

Licona, A. C., \& Maldonado, M. M. (2014). The social production of Latin@* visibilities and invisibilities: Geographies of power in small town America. Antipode, 46(2), 517-536. 
Lilja, M. (2017). Dangerous bodies, matter and emotions: Public assemblies and embodied resistance. Journal of Political Power, 10(3), 342-352.

Lundberg Tuorda, T. (2014). Life as a Sami activist: My struggle for a mining-free Gállok-Jokkmokk and Kvikkjokk. In J. Gärdebo, M.-B. Öhman, \& H. Maruyama (Eds.), RE: Mindings: Co-constituting indigenous/academic/artistic knowledges (pp. 199210). Uppsala: Hugo Valentin Centre.

Martinsson, L., Griffin, G., \& Giritli Nygren, K. (Eds.). (2016). Challenging the myth of gender equality in Sweden. Chicago, IL: The University of Chicago Press.

Morgan, M. (2017). Women, gender and protest: Contesting oil palm plantation expansion in Indonesia. The Journal of Peasant Studies, 44(6), 1177-1196.

Müller, A. (2013). Smutsiga miljarder [Dirty billions]. Skellefteå: Ord \& Visor Förlag.

Müller, A. (2015). Norrlansparadoxen [The paradox of the land in the North]. Skellefteå: Ord \& Visor Förlag.

Nabulivou, N. (2006). Feminisms, identities, sexualities: A personal journey. Development, 49(1), 30-34.

Näringsdepartementet. (2013). Sveriges mineralstrategi: för ett hållbart nyttjande av Sveriges mineraltillgångar som skapar tillväxt i hela landet [Sweden's mineral strategy: For a sustainable usage of Sweden's mineral resources that creates growth in the whole country]. Stockholm: Regeringskansliet.

Nordin, J. (2015). Metals of metabolism: The construction of industrial space and the commodification of the early modern Sami. In M. P. Leone \& J. E. Knauf (Eds.), Historical archaeologies of capitalism: Contributions to global historical archaeology (pp. 249-272). New York, NY: Springer.

Persson, M., \& Öhman, M. (2014). Visions for a future at the source: The battle against the Rönnbäck nickel mining project. In J. Gärdebo, M.-B. Öhman, \& H. Maruyama (Eds.), RE: Mindings: Co-Constituting indigenous/academic/artistic knowledges (pp. 103-119). Uppsala: Hugo Valentin Centre.

Pini, B., \& Mayes, R. (2013). Gender, sexuality and rurality in the mining industry. In A. Gorman-Murray, B. Pini, \& L. Bryant (Eds.), Sexuality, rurality and geography (pp. 187-198). Lanham, MD: Lexington Books.

Rice, R. (2012). The new politics of protest: Indigenous mobilization in Latin America's neoliberal era. Tucson, AZ: University of Arizona Press.

Sandström, M. (2017). DeCo2onising Aktivism [DeCO2onising Activism]. In M. Liliequist \& C. Cocq (Eds.), Samisk kamp: Kulturförmedling och rättviserörelse [Sami struggle: Cultural communication and rights movement]. Umeå: Hströms Förlag.

Sassen, S. (2013). Expulsions: Brutality and complexity in the global economy. Cambridge, MA: Harvard University Press.
Sjöstedt Landén, A. (2014). Gruvboom och gruvkamp: Anteckningar från Gállok-Kallak [Mining boom and mining struggle: Notes from Gállok-Kallak]. Kulturella Perspektiv, 1, 23.

Sjöstedt Landén, A. (2017a). "Gruvboom kallade de det": Gruvkritik och kamp för alternativa samhällen ["Mining boom they called it": Mining critique and struggle for alternative communities]. In M. Liliequist \& C. Cocq (Eds.), Samisk kamp: Kulturförmedling och rättviserörelse [Sami struggle: Cultural communication and rights movement]. Umeå: Bokförlaget h:ström.

Sjöstedt Landén, A. (2017b). En berättelse om gruvmotstånd: En berättelse om Norrland? [A story about mining resistenca]. In A. Öhman \& B. Nilsson (Eds.), Brännpunkt Norrland: Perspektiv på en region i förändring [Focal point Norrland: Perspectives on a changing region]. Umeå: Bokförlaget $h$ :ström.

Sjöstedt Landén, A., \& Olofsdotter, G. (2016). "What should we do instead?" Gender-equality projects and feminist critique. In L. Martinsson, G. Griffin, \& K. Giritli Nygren (Eds.), Challenging the myth of gender equality in Sweden (pp. 163-186). Chicago, IL: The University of Chicago Press.

Stienstra, D. (2015). Northern crises: Women's relationships and resistances to resource extractions. International Feminist Journal of Politics, 17(4), 630-651.

Stuermer, M. (2013). 150 years of boom and bust: What drives mineral commodity prices? (MPRA Paper No. 51859). University of Bonn, Germany.

Thomas, S. (2013, July 4). Mining revival offers hope in crisis-hit Europe. Reuters. Retrieved from uk.reuters. com/article/mining-europe-idUKL5NOF92SQ20130704

Tidholm, P. (2012). Norrland [The land in the North]. Luleå: Teg Publishing.

Tillväxtanalys. (2016). Sverige: Ett attraktivt gruvland $i$ världen? En internationell jämförelse [Sweden: An attractive mining nation in the world? An international comparison]. Östersund: Myndigheten för tillväxtpolitiska utvärderingar och analyser.

Tsavdaroglou, C., Petrakos, K., \& Makrygianni, V. (2017). The golden "salto mortale" in the era of crisis. City, 21(3/4), 428-447.

Vaiou, D. (2014). Tracing aspects of the Greek crisis in Athens: Putting women in the picture. European Urban and Regional Studies, 18(2), 254-274.

Verloo, M., \& van der Vleuten, A. (2009) The discursive logic of ranking and benchmarking. In E. Lombardo, P. Meier, \& M. Verloo (Eds.), The discursive politics of gender equality: Stretching, bending and policymaking. London: Routledge.

Willow, A. J. (2016). Indigenous ExtrACTIVISM in boreal Canada: Colonial legacies, contemporary struggles and sovereign futures. Humanities, 5(3), 55. 


\section{About the Authors}

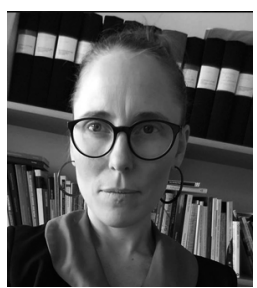

Angelika Sjöstedt Landén is a Senior Lecturer in Gender Studies at Mid Sweden University, Sweden and holds a PhD in Ethnology. She currently works in the research project "Rural morality: Meaning, mobilization and citizenship in initiatives for a sustainable rural Swedish North", led by Professor in Ethnology Anna Sofia Lundgren at Umeå University and funded by the Swedish Research Council. She has published several articles on gender equality policy, geography and identity.

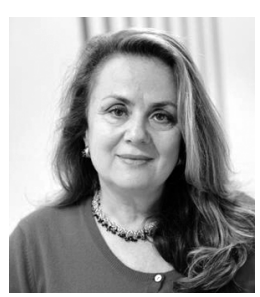

Marianna Fotaki is Professor of Business Ethics at University of Warwick Business School, UK. She holds degrees in medicine and has obtained her PhD from the London School of Economics and Political Science. Recent books include Diversity, Affect and Embodiment in Organizing (Palgrave 2019, coedited with Alison Pullen). Marianna's currently works on whistleblowing (funded by the ESRC and British Academy/Leverhulme Trust), solidarity responses to crisis, and refugee arrivals in Greece. 